\title{
1. The peace and security judgments: the role of the International Court of Justice in the regulation of the use of force
}

\author{
Mónica Pinto
}

The maintenance of international peace and security is the very first purpose of the United Nations. ${ }^{1}$ The International Court of Justice, which has a clear understanding of the goal and of its role in achieving it, is the single most important source of international jurisprudence in this area.

Contemporary international law relating to the use of force is embodied in two United Nations Charter provisions: article 2(4) establishes the rule of abstention from the threat or the use of force by states against the territorial integrity or political independence of any state, or in any other manner inconsistent with the purposes of the United Nations; and article 51 embodies the exception, by allowing the exercise of the inherent right of individual or collective self-defense in case of an armed attack against a Member of the United Nations, until the United Nations Security Council has taken the measures necessary to maintain peace and security. All states are bound by these same two norms, which, it has to be noted, have raised multiple interpretations. ${ }^{2}$

1 Charter of the United Nations (1945) (concluded 26 June 1945, entered into force 24 October 1945) 892 UNTS 119 art 1(1).

2 Rosalyn Higgins, 'International Law and the Avoidance, Containment and Resolution of Disputes - General Course on Public International Law' (1991) 231 Recueil des Cours 307. Other developments such as the United Nations General Assembly resolutions 'Essentials of Peace' (01 December 1949) UN Doc A/RES/4/290; 'Declaration on Principles of International Law Concerning Friendly Relations and Cooperation Among States in Accordance with the Charter of the United Nations' (24 October 1970) UN Doc A/RES/2625; 'Definition of Aggression' (14 December 1974) UN Doc A/RES/3314 (XXIX); 'Declaration on the Enhancement of the Effectiveness of the Principle of Refraining from the Threat or Use of Force in International Relations' (18 November 1987) UN Doc A/RES/42/22, did not create new rules. 
From its judgment in the Court's very first case, the Corfu Channel case, ${ }^{3}$ to the landmark Nicaragua case - the single pre-eminent judgment in this area for many reasons, including its recognition of a customary international corpus juris on the use of force by states ${ }^{4}$ - and afterwards, the International Court of Justice has developed a sustainable case law on the use of force in international law. The following pages will underline some aspects of the Court's case law in the area of peace and security the illegality of the unilateral uses of force by states, the necessary threshold for a use of force to give rise to an entitlement to self-defense, and the complementarity of the action by United Nations organs in this field - and shed light on their details.

\section{THERE IS A CUSTOMARY INTERNATIONAL LAW ON THE USE OF FORCE}

When faced with Nicaragua's application to the International Court of Justice, the United States of America invoked its reservation to the Court's jurisdiction, according to which in disputes arising under a multilateral treaty, all state parties to the treaty should be parties to the case before the Court. Counsel argued that this should lead to the exclusion of the United Nations Charter and, at the same time, should provide a reasonable exit of the case to the United States, which enriched this position with a peculiar reading of the codification of customary rules. 5 The move was, however, unsuccessful. The Court did not hesitate to confirm that ' $[\mathrm{t}] \mathrm{here}$ can be no doubt that the issues of the use of force and collective self-defense raised in the present proceedings are issues which are regulated both by customary international law and by treaties, in particular the United Nations Charter' ${ }^{6}$

The customary law on the use of force as decided in this 1986 judgment relied on the grounds of a previous holding by the Court on the special nature of those rules. In the Barcelona Traction case of 1970 the Court had stated that:

3 Corfu Channel Case (UK v Albania) (Merits) [1949] ICJ Rep 4 (Corfu Channel case).

4 Military and Paramilitary Activities In and Against Nicaragua (Nicaragua v USA) (Merits) [1986] ICJ Rep 14 (Nicaragua case).

5 Ibid [392].

6 Ibid [34]. 
an essential distinction should be drawn between the obligations of a State towards the international community as a whole, and those arising vis-à-vis another State in the field of diplomatic protection contracts with respect to some other States and those it has with respect to the whole community of States: By their very nature the former are the concern of all States. In view of the importance of the rights involved, all States can be held to have a legal interest in their protection; they are obligations erga omnes. Such obligations derive, for example, in contemporary international law, from the outlawing of acts of aggression ...7

It has been wisely noted that:

In itself, the Court's judgment is carefully reasoned, but risky. The public appeal of an independent customary international law against the use of force in international relations is powerful. Since this appeal recognizes the norm as a principle of world order free from the Charter structure, perhaps it also partakes the same dangers that inhere in the concept of jus cogens. As Ian Sinclair well understood, jus cogens has the potential of both Dr. Jekyll and Mr. Hyde. ${ }^{8}$

\section{THE INTERNATIONAL COURT OF JUSTICE CONFIRMS THE PROHIBITION OF UNILATERAL USE OF FORCE BY STATES}

From its very first judgment in a contentious case in 1949, the Corfu Channel case, the International Court of Justice has declared without hesitation that the United Nations Charter prohibits any unilateral measure of force except the inherent right to self-defense. The Court considered that '[b]etween independent States, respect for territorial sovereignty is an essential foundation of international relations', so it decided that 'to ensure respect for international law, of which it is the organ, the Court must declare that the action of the British Navy [conducting mine clearance operations without consent of the territorial state] constituted a violation of Albanian sovereignty'. ${ }^{2}$ In this foundational moment the Court identified itself as the organ of international law - a condition it

\footnotetext{
7 Barcelona Traction, Light and Power Company Ltd (Belgium v Spain) (Judgment) [1970] ICJ Rep 3 (Barcelona Traction case) [33]-[34].

8 Gordon A Christenson, 'The World Court and Jus Cogens' (1987) 81 American Journal of International Law 93 in Harold G Maier (ed), 'Appraisals of the ICJ's Decision: Nicaragua v United States (Merits)' (1987) 81 American Journal of International Law 77.

9 Corfu Channel case (n 3) [35].
} 
later emphasized in the Genocide case (examining the legal nature of the massacre at Srebrenica), by asserting precedence over the jurisprudence of another international tribunal, the International Criminal Tribunal for the former Yugoslavia, in international law matters ${ }^{10}$ - citing the crucial character of the prohibition of the use of force in such legal order. ${ }^{11}$

Even though the Corfu Channel case finding of a violation of territorial sovereignty provided enough ground to establish that the United Kingdom had incurred international responsibility, the Court decided to go further. Challenging the statement by the United Kingdom that the minesweeping operation was a self-help measure, the Court affirmed that:

[the Court] can only regard the alleged right of intervention as the manifestation of a policy of force, such as has, in the past, given rise to most serious abuses and such as cannot, whatever be the present defects in international organization, find a place in international law. Intervention is perhaps still less admissible in the particular form it would take here; for, from the nature of things, it would be reserved for the most powerful States, and might easily lead to perverting the administration of international justice itself. ${ }^{12}$

Early in the 1980s, in the context of the American hostage crisis in Iran, the Court condemned the failed American operation over Iranian territory (intended to rescue the hostages from the United States Embassy in Tehran) notwithstanding the fact that, as put by the United States Government, it had been conducted 'in exercise of its inherent right of self-defense'. In its judgment in United States Diplomatic and Consular Staff in Tehran (the Iran Hostage Crisis case), the Court referred to its duty of not letting pass without comment uses of force involved in the cases brought to it. ${ }^{13}$ It affirmed that 'an operation undertaken in those circumstances, from whatever motive, is of a kind calculated to undermine respect for the judicial process in international relations' ${ }^{14}$ It has been pointed out that this judgment is where the tribunal started its

10 Application of the Convention on the Prevention and Punishment of the Crime of Genocide (Bosnia and Herzegovina v Serbia and Montenegro) (Judgment) [2007] ICJ Rep 43 (Genocide case).

11 Thomas Franck, Recourse to Force: State Action against Threats and Armed Attacks (Cambridge University Press 2002) 11; Higgins (n 2) 308.

12 Corfu Channel case (n 3) [35].

13 United States Diplomatic and Consular Staff in Tehran (USA v Iran) (Judgment) [1980] ICJ Rep 3 (Iran Hostage Crisis case) [43].

14 Ibid. 
doctrine on contempt of the Court, ${ }^{15}$ and that it did so to enshrine respect for the judicial function of the Court as an independent mechanism for examination of the behavior of parties in disputes involving the threat or use of force. In doing so, the Court also established that it is, first of all, the guardian of the judicial process it heads. ${ }^{16}$

These expressions by the Court constitute a warning to the whole community of states on its perception and legal qualification of the unilateral uses of force by states. They allow us to infer that the International Court of Justice has a firm judicial policy regarding unilateral uses of force by states. Indeed, the Court's willingness to express itself on the uses of force by states is large enough to include cases in which it manifestly lacked jurisdiction. These rulings emphasize that, for the Court, there is a fundamental distinction between the question of the acceptance by a state of the Court's jurisdiction and the compatibility of particular acts with international law.

In 1999, in the context of the cases brought by Yugoslavia against North Atlantic Treaty Organization Member States, the International Court of Justice came back to comments on the use of force. The Court was 'profoundly concerned with the use of force in Yugoslavia [which] under the present circumstances ... raises very serious issues in international law'; it stressed its own role in the maintenance of peace and security under the Charter and the Statute of the Court and emphasized that 'all parties appearing before it must act in conformity with their obligations under the United Nations Charter and other rules of international law, including humanitarian law' and that 'whether or not States accept the jurisdiction of the Court, they remain in any event responsible for acts attributable to them that violate international law, including humanitarian law'; and it furthermore provided a reminder of the duty to settle by peaceful means disputes giving rise to a threat to the peace, breach of the peace or act of aggression, and the special responsibilities of the Security Council under chapter VII of the Charter. ${ }^{17}$

15 Ted L Stein, 'Contempt, Crisis and the Court: The World Court and the Hostage Rescue Attempt' (1982) 76 American Journal of International Law 499, 505.

16 Shabtai Rosenne, The World Court: What It Is and How It Works (Terry D Gill ed., 6th edn, Martinus Nijhoff 2003) 29.

17 Legality of Use of Force (Yugoslavia v Belgium) (Yugoslavia v Canada) (Yugoslavia v France) (Yugoslavia v Germany) (Yugoslavia v Italy) (Yugoslavia v Netherlands) (Yugoslavia v Portugal) (Yugoslavia v Spain) (Yugoslavia v UK) (Yugoslavia v USA) (Provisional Measures Order) [1999] ICJ Rep 124 (NATO cases) [47]-[50]. 
This reminder is the more eloquent expression of the illegality of the acts the International Court of Justice is often prevented from judging by reason of limitations on its jurisdiction. It also clearly endorses the complementarity in the action of both organs - that is, the Court itself and the United Nations Security Council.

\section{WHO JUDGES THE USES OF FORCE CONTRARY TO INTERNATIONAL LAW?}

In the allocation of power among its main organs, the United Nations Charter dealt with the maintenance of international peace and security in chapters VI, VII and VIII, all of which are the main domain of the Security Council. While the Charter has no specific provision dealing with the monitoring of adherence to the principle contained in article 2(4) or article 2(3) requiring the settlement of international disputes by peaceful means, it provides that the Security Council should - in exercising its right to recommend appropriate procedures or methods of adjustment of disputes under article 36 - 'take into consideration that legal disputes should as a general rule be referred by the parties to the International Court of Justice'. This combination leads to the conclusion that, while the Charter has its own mechanism headed by the Security Council to deal with threats to the peace or breaches of the peace which may or may not involve the use of force - the International Court of Justice is the competent organ to deal with the conventional and customary principle of the prohibition of the use of force by states and the principle of self-defense in case of armed attack. In theory, neither of these organs necessarily excludes the involvement of the other.

While it can hardly be imagined that in the context of an armed conflict the parties could seize the International Court of Justice for a ruling confirming the legality of their conduct, it has happened that states involved in a situation of use of force have seized the Court with a view to obtaining a ruling that could help the situation become more manageable. That was the situation during the crisis of the American hostages in Iran that led to the Iran Hostage Crisis case, and the intent of the Sandinista Government in the Nicaragua case.

Conversely, states challenging the jurisdiction of the Court have tried two sets of arguments, namely, the Security Council's monopoly on the authorized use of force and, secondly, the existence of an actual armed conflict. Neither proved to be effective.

The idea that the United Nations Security Council has been conferred with primary - but not exclusive - responsibility for the maintenance of 
peace and security dates back to the Korean War. In 1951, for the first time, the United Nations General Assembly, enforcing Resolution 377(V) Uniting for Peace, adopted Resolution 498(V) finding that the People's Republic of China had engaged in aggression in Korea. Though this was not equivalent to a binding decision by the United Nations Security Council, as provided for by article 25 of the United Nations Charter (requiring Member States to carry out Security Council decisions in accordance with the Charter), it was a clear statement by the great majority of the international community condemning China's action. The Court confirmed this position in its 1970 advisory opinion on Namibia, ${ }^{18}$ later in the Iran Hostage Crisis case, ${ }^{19}$ and again in its judgment in the Nicaragua case, where it made the clearest distinction:

Until the Security Council makes a determination under Article 39, a dispute remains to be dealt with by the methods of peaceful settlement provided under Article 33, including judicial settlement; and even after a determination under Article 39, there is no necessary inconsistency between Security Council action and adjudication by the Court. ${ }^{20}$

Furthermore, it underlined that ' $[\mathrm{t}]$ he Council has functions of a political nature assigned to it, whereas the Court exercises purely judicial functions. Both organs can therefore perform their separate but complementary functions with respect to the same events'. ${ }^{21}$

In the Nicaragua case, the Court also dealt with the argument of the actual armed conflict as an objection to its jurisdiction and it did so in a way consistent with its own practice, stating that '[the Court] is asked to pass judgment on certain legal aspects of a situation which has also been considered by the Security Council, a procedure which is entirely consonant with its position as the principal judicial organ of the United Nations'. ${ }^{22}$

The same doctrine was put forward by the Court in the Lockerbie cases, where it underlined the obligation on both Libya and the United Kingdom (also the United States of America in the parallel case) - as

18 Legal Consequences for States of the Continued Presence of South Africa in Namibia notwithstanding Security Council Resolution 276 (1970) (Advisory Opinion) [1971] ICJ Rep 16 (Namibia Advisory Opinion) [21]-[22].

19 Iran Hostage Crisis case (n 13).

20 Military and Paramilitary Activities In and Against Nicaragua (Nicaragua v USA) (Jurisdiction and Admissibility) [1984] ICJ Rep 392 (Nicaragua case, Jurisdiction and Admissibility Decision) [90].

21 Ibid [95].

22 Ibid [98]. 
Members of the United Nations - to accept and carry out the decisions of the Security Council in accordance with article 25 of the United Nations Charter, and that such duty prevailed at the stage of proceedings on provisional measures and, prima facie, over their obligations under any other international agreement, including the Montréal Convention. ${ }^{23}$ On this basis, the Court rejected Libya's request for the indication of provisional measures. The Court stressed the fact that the measures requested by Libya would be likely to impair the rights which appeared to be enjoyed by the United Kingdom (and also by the United States) by virtue of the Security Council resolution. Thus, complementarity between the two organs is clearly the position of the International Court of Justice.

This explains why even though the Security Council may remain silent on a given situation, the Court may afterwards judge that it involved a breach of article 2(4). That is, inaction by the Security Council does not absolve a state in the case of a prohibited unilateral use of force.

\section{NOT ALL USES OF FORCE LEAD TO SELF-DEFENSE}

In the Nicaragua case the International Court of Justice draws a distinction between different uses of force, with a view to raising the level of the use of force that authorizes the exercise of the inherent right of self-defense. It does so on the grounds of customary international law because the United Nations Charter fell outside the scope of its decision, due to the United States reservation on its acceptance of jurisdiction under article 36(2) of the Court's Statute. The Court distinguishes 'the most grave forms of the use of force (those constituting an armed attack) from other less grave forms', ${ }^{24}$ and accordingly concludes that 'while an armed attack would give rise to an entitlement to collective self-defense, a use of force of a lesser degree of gravity cannot ... produce any entitlement to take collective counter-measures involving the use of force'.$^{25}$

23 Questions of Interpretation and Application of the 1971 Montréal Convention Arising from the Aerial Incident at Lockerbie (Libya $v$ UK) (Provisional Measures Order) [1992] ICJ Rep 3 [41]; Questions of Interpretation and Application of the 1971 Montréal Convention Arising from the Aerial Incident at Lockerbie (Libya v USA) (Provisional Measures Order) [1992] ICJ Rep 114 [44] (Lockerbie cases).

$24 \quad$ Nicaragua case (n 4) [191].

25 Ibid [249]. 
It follows that, notwithstanding the wording of United Nations General Assembly Resolution 3314 on the Definition of Aggression, according to which the United Nations Security Council may determine that other acts constitute aggression under the provisions of the Charter, it is the Court that determines the scope of aggression. This explains why the Congolese memorial in Armed Activities on the Territory of Congo refers to 'an act of aggression within the meaning of Article 1 of resolution 3314 of the General Assembly of the United Nations of 14 December 1974 and of the jurisprudence of the International Court of Justice, contrary to Article 2, paragraph 4, of the United Nations Charter' ${ }^{26}$

As observed by Michael Reisman, the Court chose this approach because 'it was persuaded that the level of unauthorized violence in the international political system would be lower; and such choice will inevitably be appraised in terms of its contribution to the goals of international law and, in particular, its effect on the maintenance of minimum order' ${ }^{27}$

\section{THE CUSTOMARY REQUIREMENTS OF THE INHERENT RIGHT TO SELF-DEFENSE}

In the same line of arguments, in its judgment in the Nicaragua case, the Court asserts the restrictive scope of the right of self-defense, especially collective self-defense, stressing the importance of the criteria of necessity and proportionality - even as its decision at the same time enlarges the field and the modalities of lawful self-defense. ${ }^{28}$ The Court declares that the attacked state should not only declare itself as having been attacked but should also request collective self-defense. ${ }^{29}$ It adds the customary elements of necessity and proportionality, described in the judgment on the Oil Platforms case:

in order to establish that [the United States of America] was legally justified in attacking the Iranian platforms in exercise of the right of individual

26 Armed Activities on the Territory of Congo (DRC v Uganda) (Judgment) [2005] ICJ Rep 168 [23].

27 W Michael Reisman, 'The Political Consequences of the General Assembly Advisory Opinion' in Laurence Boisson de Chazournes and Philippe Sands (eds), International Law, the International Court of Justice and Nuclear Weapons (Cambridge University Press 1999) 474.

28 Pierre-Marie Dupuy, Droit International Public (7th edn, Dalloz-Sirey 2004) 594-5.

29 Nicaragua case (n 4) [199]. 
self-defense, the United States has to show that attacks had been made upon it for which Iran was responsible; and that those attacks were of such a nature as to be qualified as 'armed attacks' within the meaning of that expression in Article 51 of the United Nations Charter, and as understood in customary law on the use of force ... The United States must also show that its actions were necessary and proportional to the armed attack made on it, and that the platforms were a legitimate military target open to attack in the exercise of self-defense. ${ }^{30}$

This is a reversal of the standard burden of proof.

\section{THERE IS A LINK BETWEEN PROHIBITED USE OF FORCE AND THE PROHIBITION ON INTERVENTION}

The relation between the use of force and intervention was evoked by the Court in its ruling in the Nicaragua case, where it concluded that 'acts constituting a breach of the customary principle of non-intervention will also, if they directly or indirectly involve the use of force, constitute a breach of the principle of non-use of force in international relations' ${ }^{31} \mathrm{In}$ the same judgment, the Court provided for nuances when it affirmed that the international law in force does not provide for an armed response in case of intervention because there is no rule establishing the role of the right to self-defense in cases of intervention. ${ }^{32}$

\section{SOME CONCLUSIONS}

The International Court of Justice has been diligent in its contribution to the maintenance of peace and security. In the cases brought before it, the Court has not let pass without comment any unilateral use of force by a state or group of states, including those cases in which the Court manifestly lacked jurisdiction. The International Court of Justice has also raised the threshold for the use of force entitling self-defense, thus restricting the legality of unilateral responses to a use of force. It has added requirements of necessity and proportionality to the use of force in self-defense. It was wise enough to keep for itself the judgment on the

\footnotetext{
30 Oil Platforms (Iran v USA) (Judgment) [2003] ICJ Rep 161 (Oil Platforms case) [51].

31 Nicaragua case (n 4) [109]-[110].

32 Ibid [211].
} 
observance or the breach of the rule - both customary and conventional on the prohibition of the use of force by states and on the right to self-defense. It has also built up a relationship with the United Nations Security Council so that their actions are complementary.

The Court's speech reveals the dimensions of its role as the main judicial organ of the United Nations with respect to its responsibilities in the achievement of the United Nations' first institutional goal. In short, the Court adjudicates on claims with a view to the peaceful settlement of disputes. 